\title{
AGGLOMERATION EFFECTS AND PERFORMANCE: A TEST OF THE TEXAS LODGING INDUSTRY
}

\author{
WILBUR CHUNG \\ New York University \\ ARTURS KALNINS \\ University of Southern California
}

\begin{abstract}
While competition decreases rents for firms, the presence of competitors may create benefits. Competitors that agglomerate, that are physically proximate, may create externalities-production efficiencies or heightened demand that increases rents. When such externalities exist, then who gains from and who contributes to them? We examine how other competitors' traits affect performance in Texas's lodging industry. In rural markets, we find that chain hotels and larger hotels contribute to positive externalities. While expecting those hotels similar to the establishments creating these externalities to gain, we find the opposite. Independent hotels and smaller hotels gain the most. Interestingly, some establishments are harmed.
\end{abstract}

Basic economic models of spatial competition predict that firms locate more distantly from each other to enjoy profitable local monopolies. When firms locate closer to each other, they realize lower rents. This suggests that proximity is often synonymous with competition. Besides physical location, proximity can be measured along other dimensions of product space-firms may differentiate on price, quality, and features to avoid proximate competition. ${ }^{1}$ Proximity may also be measured using organizational traits. For example, Baum and Mezias (1992) demonstrate that those competitors with similar traits are greater threats to each other. In the Manhattan hotel industry, establishments that are more proximate in location, price, and physical size reduce each other's probability of survival. Proximity in physical location, product space, and organizational traits increases competition. Heightened competition reduces rents for all.

Economists have, however, long acknowledged the opposite possibility: proximate competitors might be beneficial. Most notably, Marshall (1920) suggests that firms can gain from agglomeration: those external economies available to firms in large concentrations of economic activity that arise because large markets allow wider choice and greater range of specialized services. Marshall describes two types of gains: production enhancements and heightened demand. For production enhancements, flow of information between firms, aided by proximity, permits more firms access to leading techniques. Agglomeration will cause heightened demand in industries where consumers need to personally inspect goods. Sellers can reduce consumers' search costs by spatially concentrating. Physical collocation helps consumers evaluate the options presented by these multiple collocated firms; thereby

\footnotetext{
${ }^{1}$ For a summary of such models see Tirole (1988: 279).
} 
increasing the likelihood of visitation and purchase versus if the firms had located separately. We term these external economies accruing from firms collocating as "agglomeration effects". In certain settings, gains from agglomeration can outweigh the losses from competition.

Organizational researchers have also been aware of the competing tension between competition and agglomeration. Recognizing a specific type of agglomeration gain, Barnett and Carroll (1987) demonstrate "mutualism" - that the proximity of neighboring companies can be beneficial for a company's survival when such neighbors are differentiated but have inter-linked demand. Testing the repulsion of competition versus the draw of agglomeration gains in the Manhattan hotel industry, Baum and Haveman (1997) find that new hotels establish themselves at similar prices but of different sizes to those around them, which is consistent with managers trading off losses and gains from proximity. These organizational studies highlight the importance of firm traits in understanding this basic economic relationship.

With agglomeration effects, while the basic economic relationship is that collocation is more likely to occur when participating firms benefit from each other's presence, unanswered questions arise once firm heterogeneity is introduced. In this paper we explore two questions. First, what types of firms contribute more to these external economies? Second, what types of firms benefit more? Of the two types of agglomeration effects, we focus on agglomeration demand gains because they have been less studied by organizational scholars and because of our empirical context. ${ }^{2}$ We choose a setting where such demand gains are likely to arise: the lodging industry. ${ }^{3}$ Selecting a hotel involves consumer search costs, because description of quality and services via guide books and by telephone may be inadequate. Personal visual inspection may be required to determine whether a particular establishment provides acceptable, desired product attributes. The consumer may need to know, for example, whether the hotel is in a safe area, or whether it is too close to the highway.

We suggest that firms that signal their existence and whose signals contain information of potentially desirable firm traits will contribute to agglomeration benefits. Similarly, since the consumers attracted will mainly be seeking those traits signaled, we expect only firms that are similar to those doing the signaling to benefit from agglomeration demand externalities. In other words, benefits will be "localized" along various organizational traits. To identify important organizational traits, we use concepts identified in earlier works on the lodging industry. Baum and Mezias (1992) find that a hotel's competitors and customers are partly determined by the hotel's physical size. Ingram and Baum (1997) find that chain affiliation aids survival.

Our empirical setting is the population of hotels and motels operating in Texas during 1992. We examine revenues per room as our dependent variable, which is an industry standard measure of performance. We expect larger, chain affiliated hotels to have attributes more desirable to consumers. We develop detailed arguments for

\footnotetext{
${ }^{2}$ We know a good deal about production enhancements. Supporting the link between information flows and proximity, Jaffe, Tratjenberg, and Henderson (1993) show that firms physically located closer to each other are more likely to cite each others' patents. Appleyard (1996) further shows that not only informal exchanges between scientists, but public forums such as conferences also facilitate information flows. These types of information flows will enhance organizations' performance. Consistent with gains from information spillovers, Shaver (1997) shows subsequent foreign entrants have heightened survival. Recently, Shaver and Flyer (2000) shows strong entrants might purposefully try to slow information spillovers by locating distantly. In contrast, we know less about how agglomeration affects demand. While antecedents of agglomeration have attracted significant attention from industrial organizational economists (see for example Eaton and Lipsey (1982), Stahl (1982), and West (1992)), measurement of demand agglomeration gains have attracted little attention from economists or organizational scholars.

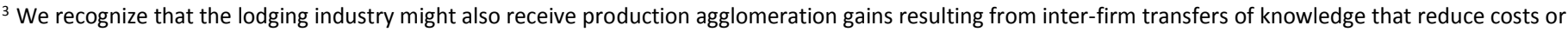
otherwise enhance production.
} 
this expectation in the theory section. The agglomeration of such hotels will create heightened demand-the number of consumers will increase beyond the sum that the hotels might have otherwise attracted when located separately because consumers are more likely to find the firm traits that they prefer.

Answering the questions, "Which firms contribute most to these external economies?" and "Which firms benefit more?" is important for managers making strategic location decisions. Clearly managers will need to make tradeoffs between competition costs and agglomeration gains that result from proximity. When choosing among different locations, managers can assess ex ante where agglomeration gains are more likely to exist. Importantly, managers can assess whether these gains will be beneficial for their particular firm.

We find that agglomeration gains exist in rural markets where firms' actions to reduce consumers' search costs are most effective. In rural markets, large hotels and chain affiliated hotels contribute to heightened demand. Also, opposite of our hypotheses, we find that establishments dissimilar to those heightening demand gain more from this externality. Smaller hotels and independent hotels do better in markets populated by more large and chain affiliated hotels. Interestingly, we find that some establishments can be harmed-enjoying lower revenue performance than if there was no agglomeration. These findings suggest that firms should select their locations with care. Inappropriate location choice is potentially harmful.

We proceed as follows. After briefly summarizing prior research on origins of agglomeration effects, we develop expectations for who contributes to and who gains from agglomeration demand externalities. Next we introduce our empirical context and our test methodology. Results and discussion follow. Finally, we conclude with future improvements.

\section{COMPETITION AND AGGLOMERATION EFFECTS}

Proximity is normally associated with greater competition. The presence of more sellers means reduced prices and/or sales for all. But proximity need not always be detrimental. External benefits may arise from firms agglomerating - from firms locating close to each other.

Agglomeration gains of two types exist: those yielding production enhancements and those yielding heightened demand. Both effects have common roots in the value of information and originate with Marshall (1920). In his explanation of agglomeration production enhancements, Marshall notes certain articles were only made in one geographical location. He provides several explanations including the concentration in one place of necessary physical inputs and demand. The concentration of production provides stability, which provides incentives for skilled trades to invest in specialized skills. The proximity of skilled trades people to each other then allows knowledge of a production improvement to quickly become available to many.

In this paper, we focus on the second type of agglomeration gain-agglomeration yielding heightened demand. Marshall also addresses this possibility, noting:

... have discussed localization from the point of view of the economy of production. But there is also the convenience of the consumer to be considered. He will go to the nearest shop for a trifling purchase; but for an important purchase he will take the trouble of visiting any part of the town where he knows that there are specialty good shops for his purpose. Consequently shops which deal in expensive and choice objects tend to 


\section{congregate together; and those which supply ordinary domestic needs do not.}

While not explicitly stating so, Marshall is concerned with information search costs. The particular consumer, while willing to visit every shop, may not know about a specialty shop's existence. By agglomerating, shops decrease consumers search costs, increasing the likelihood that consumers know of their existence, and therefore the likelihood of receiving consumers' visits.

While readily apparent to academics and the layperson alike, this idea of information search cost waits until Stigler (1961) to be more formally treated. Stigler notes that buyers and sellers need to be identified; that if we wanted to sell a used car and randomly polled individuals, the likelihood of finding a buyer is small. Markets form because they are efficient mechanisms that reduce the search costs for both buyers and sellers. The need to engage in search perpetuates because price dispersions persist as buyers and sellers enter and exit. Applying Stigler's ideas, Stahl (1982) argues that firms have the incentive to agglomerate under high search costs - when product traits require visual inspection by consumers. Dudey (1990) extends this finding of agglomeration to a setting where consumers are not searching for product attributes, but rather for low prices. Fischer and Harrington (1996) present a theoretical model showing that the more heterogeneous the product, the greater the agglomeration.

Agglomeration lowers consumer search costs, which increases the likelihood of visitation, and thereby heightens the demand experienced by agglomerating firms.

While these two agglomeration effects are often treated separately, linkages between them are possible. Production enhancements can create better quality products, which will in turn heighten demand once consumers are aware of them. For example, Baum and Ingram (1998) describe improved hotel labor practices that would enhance the quality of service experienced by visitors.

\section{LOCALIZED AGGLOMERATION GAINS}

While the industrial organization economics literature explains why heightened demand might occur, we remain uninformed as to potential asymmetries in contribution to and gains from such external economies.

Acknowledging firm heterogeneity, we ask, "Who contributes to demand externalities?" Since heightened demand occurs when consumer search costs are lowered, firms with traits that lower search costs will contribute to agglomeration effects. These traits need to inform customers about the likelihood that the firm will or will not meet the consumers' preferences. Visible firm traits include brands, association membership, awards, and other ratings by external organizations. Further, firms' actions can inform consumers of their traits. Actions such as advertising, price points, and location choice communicate information to consumers. Agglomerating firms that have desirable traits and that act to inform consumers of these traits will contribute to heightened demand. We suggest two readily observable traits that contribute to heightened demand: establishment size and brand affiliation.

Establishment size is linked to likelihood of advertising. Given that advertising is a fixed cost, firms that can spread this cost across more units will receive greater net benefits. Fixed costs suggest a minimum efficient scale for advertising to be profitable. Since larger firms should gain more from advertising efforts by spreading this fixed cost across more units, large firms should be more likely to advertise.

Advertising signals important attributes such as unobservable quality. This is especially important, Nelson (1970) argues, for "experience goods" - where quick inspection is insufficient, so that the product or service must 
be purchased and experienced for evaluation. In these settings it behooves the seller to advertise-with messages that do not provide direct informational content, but simply proclaim the product's existence in order to signal product quality. Building on Nelson's ideas, Milgrom and Roberts (1986) model advertising spending while including pricing deci- sions - an alternate mechanism to signal quality. They demonstrate that high quality producers will choose to both advertise and set high prices, since using only one signal invites low quality producers to mimic, which reduces signaling effectiveness. Subsequently, various authors including Nichols (1998) and Thomas, Shane, and Weigelt (1999) use the automotive industry as an empirical setting to test and demonstrate the positive link between advertising and new product quality.

Closely related to advertising is branding. Brand affiliation, or chain affiliation in our particular setting, is another signaling mechanism for quality discussed by Nelson. Firms create brands to signal higher unobserved quality. ${ }^{4}$ Wernerfelt (1988) argues that extending an existing brand to other products is a credible signal of quality since falsely signaling quality damages the reputation of the existing brand. Recently Rao, Qu, and Ruekert (1999) find that extending brands is a credible signal of product quality. For the lodging industry, Ingram (1996) argues that the need for brands is particularly acute; with travelers often not being repeat customers, hotels have little incentive to provide good service and therefore brands assist hoteliers to provide credible commitments to potential customers.

Beyond signaling, being part of a chain also confers other benefits. For example Darr, Argote, and Epple (1995) show that knowledge of process innovations flows more freely to members within the same chain than to unaffiliated firms. While this knowledge may be production enhancing in nature, it may also improve product quality; Darr et al. discuss a process improvement for pizza that increases yield, but also improves the pizza's appearance. These gains of useful knowledge may then yield an advantage over similarly unaffiliated firms. Ingram and Baum (1997) show chain affiliation increase hotels' survival rates though this is dependent upon each chain's historic operating experience. Therefore, beyond signaling, chain affiliation also indicates the possibilities of unique attributes some of which are likely attractive to consumers.

Having identified firm traits that heighten demand, for agglomeration benefits to result this demand has to transfer to other nearby firms. By signaling quality, large and chain-affiliated hotels attract customers who prefer to know ex ante a hotels' level of quality (likely most customers prefer to know quality ex ante). Once the customer stops in an area such as a highway exit, they can then easily compare all the hotels immediately proximate. They may simply find another hotel that they think more likely to match their preferences. Alternatively, the initial hotel where the customers wished to stay may have no vacancies, forcing them to make an alternate choice. Hotel managers have recognized the benefits of agglomeration for sharing customers in times of excess demand. Speaking about the opening of a nearby Holiday Inn Express, a Comfort Inn manager stated: "The more motels that are there, the more traffic you pull in off the interstate. We already have agreed to refer guests to each other when one is full." Therefore, we expect that:

\footnotetext{
${ }^{4}$ Beyond a firm creating brands, in our particular setting, individual establishments self-select to become part of a brand-individually owned hotels choose to apply to become franchisees. For econometrics, we know that such self-selection provides information on unobserved traits; for example those individuals who chose to go to college versus those who do not, have self-evaluated their human capital to be sufficient to gain enough from college to offset the expenses and opportunity costs. Similarly, firms self-selecting to join associations signal positive self-evaluation of their own attributes.
}

5 Roanoke Times and World News, page NRV1, October 9, 1998. 
Hypothesis 1a. The more large firms in a market; the greater the agglomeration benefits.

Hypothesis $1 b$. The more chain affiliated firms in a market; the greater the agglomeration benefits.

From a managerial perspective, more important than who contributes is who gains from agglomeration. If variation in gains exists, then firms may be able to position themselves for greater gains. To determine who gains, we need to consider the nature of heightened demand. The consumers attracted to agglomerating firms may have expectations of product attributes present including choice, quality, and price; depending upon what has been signaled to them. If a cluster of firms exists, but no product attributes are signaled; then consumers would expect any combination of possible product attributes. For example, a strip mall-as an agglomeration of storescommunicates only the presence of stores-and therefore draws undifferentiated consumers. In contrast, an outlet mall communicates presence of stores plus lower prices. Consumers drawn to an outlet mall expect lower prices versus those drawn to a non-outlet mall. A premium brand store that does not offer discount prices will benefit little from locating in the outlet mall. This is not to say that the agglomeration benefits will be zero, but depending on the elasticity of demand, the further the premium brand store's prices are away from the low price expectations of outlet mall consumers, the smaller the benefit.

The above discussion suggests that gains are contingent upon consumers' expectations. Consumers expect the product/firm attributes that are signaled. Since expectations are set by those firms that are signaling, those firms that are the most similar to those doing the signaling are the most likely to gain. Gains will be "localized". With our two traits, these arguments suggest that large or chain affiliated firms are more likely to gain because these are the types of firms more likely to signal to consumers. Consumers attracted will be seeking these types of signaled attributes. In the context of hotels, the customers who are sent from the Comfort Inn mentioned above to the neighboring Holiday Inn in times of excess demand are likely to be happy with the switch because the hotels are similar in quality and price. Formally this becomes:

Hypothesis $2 a$. The more an establishment is alike in size to others present in a market; the greater the agglomeration benefits due to size.

Hypothesis $2 b$. The more an establishment is alike in chain affiliation to others present in a market; the greater the agglomeration benefits due to chain affiliation.

We should note that there is a trade-off between competition and agglomeration benefits. Physical proximity may allow access to heightened demand, but proximity also almost certainly exposes firms to more intense competition. Thus firm managers need to decide when these potential agglomeration gains outweigh these competition costs.

Finally, we explore the possibility that agglomeration benefits vary by type of location. Since rural economic activity is more homogenous, rural hotels' actions to inform customers are likely to easily extend to other hotels in the immediate vicinity. For example, many rural hotels are merely overnight destinations in between days of travel. In such a case, advertising along the highway or the mere size of the hotel, perhaps well-lit and viewable from the highway, indicates to the consumer that the area is likely to provide a safe and comfortable overnight rest spot. Once the particular area is chosen, the consumer can more closely examine the other hotels nearby. On the other hand, the consumer may be unwilling to stop in a rural area with only one small hotel.

In contrast, the economic activity in cities and their suburbs is much more heterogeneous and therefore 
correspondence between hotels' actions to inform consumers and the gains of other proximate hotels is less direct. Further, many customers may have chosen the hotel because of its proximity to some other location or event, such as a historical landmark or a convention. In these cases, the number of hotels in an area is not likely to be the cause of any additional demand. The number of hotels is likely only to be the result of the attraction to that area.

Also, relative transportation costs decrease the likelihood of agglomeration benefits in urban areas. Relative transportation costs are identified by Ingram and Inman (1996) as explaining several findings in their study of Niagara Falls hotels. Ingram and Inman find that distance to the Falls matters less over time, which suggests that the disadvantage of being far from Niagara's focal attraction declines as technology advances which reduces transportation costs. Similar differences in transportation costs exist between (sub)urban and rural locations. The opportunity cost of transportation is lower in a city-there are many possible modes of conveyance that do not require the traveler personally know the route; if an initial hotel choice is unavailable, finding an alternative is less problematic. As a result, the benefits of agglomeration are less likely to be concentrated among other hotels in the immediate vicinity of the hotel that heightens demand. Therefore, we expect:

Hypothesis 3: Agglomeration benefits are more likely to be present in rural than in urban areas.

\section{DATA}

Our data consist of all Texas establishments that file taxes as hotels or motels in 1992 and that have more than twenty five rooms. ${ }^{6}$ While we have data for all establishments down to those listing one room, we use a twenty five room cut-off since numerous types of small establishments are not representative for a study focusing on hotels and motels. We exclude bed \& breakfasts, which do not operate in the same segment as hotels and motels; bed \& breakfasts are often destinations themselves, while hotels and motels are temporary housing on the way to or proximate to travelers' end destinations. Also we want to exclude people renting out one or several rooms in their private home, or those renting out their four-bedroom beachfront condo. Such cases of B\&B's, rental rooms, and time-share condos are very frequent in the raw data set. After applying the greater than twenty five rooms cutoff, roughly 1,100 establishments remain. We use quarterly data from 1992 since most of our control variables are from that year. For the four quarters of 1992, we have 4,652 total observations.

Our raw data, which come from the Texas state government, provide a hotel's name, location, owner name, owner location, size in rooms, and revenues. We supplemented the raw data in several areas. First, since the four quarterly data sets have no unique establishments identifiers - for example there is no identifier number to link "EMILY MORGAN HOTEL" in 1992Q2 data to "THE EMILY MORGAN HOTEL" in 1992Q3 data, we matched the four quarterly data sets using establishment names and addresses. Second, we eliminated miscoded values for establishments' revenues and number of rooms. Occasionally, an establishment would see increases in their revenues or number of rooms that were several multiples of their historic average. Third, we linked the Texas hotel

\footnotetext{
${ }^{6}$ Our setting is different from the Manhattan hotel industry used by Baum and Mezias (1992) and Ingram and Baum (1997) in three ways: (i) we do not have a long history, but a very short panel approaching a cross-section; (ii) instead of one market, we have several hundred markets when using the zip code level; and (iii) instead of survival, we have an outcome with greater variation across time-revenue per room. While anticipating similar findings on the localized nature of competition to Baum and Mezias (1992); these differences, especially the number of markets allow us to explore the nature of agglomeration effects using cross market variation.
} 
data to control variables drawn from the 1990 Population Census and the 1992 Economic Census-Zip Code Statistics.

For our dependent variable, given our focus on agglomeration yielding heightened demand, we use revenues per room (REV/ROOM), which is an industry standard performance measure. Heightened demand should increase hotels' occupancy or allow hotels to hike their prices, or a combination of both. All these possibilities increase revenues. Instead of just total revenues, we scale a hotel's revenues by its number of rooms since we are interested in an establishment's performance relative to its size. Large hotels are clearly going to have higher revenues than smaller hotels; we ask if a hotel performs better than other hotels, given its size. Investigating revenues per room is also appropriate given our focus on agglomeration demand effects rather than production effects. Agglomeration production effects should lower costs, while demand effects should raise revenues. Thus revenues per room should capture agglomeration gains for demand, which is our focus, while omitting most production agglomeration effects.

To explain hotels' revenue performance, we make use of cross-market variation in agglomeration. For our definition of a market, we use the five-digit zip code level since this is the finest level of detail available in the Texas hotel and control variable data. We use the most disaggregate level available to retain as much variation as possible. Texas provides an attractive empirical context given its large size and 487 five-digit zip code markets.

Within a market, we need to account for what besides agglomeration effects determines a hotel's revenue performance. To explain hotels' revenue performance, we include four categories of determinants: market demand conditions, market supply conditions, an establishment's own traits, and market agglomeration conditions. A hotel in a market with higher demand will have greater revenue per room. A hotel in a market with greater supply will have lower revenue per room. More expensive, higher quality hotels will have greater revenue per room.

For market demand control variables we include each markets' population in 1990 (POP), per capita income in 1989 (PCI), land in 1990 (LAND), the number of homes in 1990 (HOMES), the count of retail establishments in 1992 (RET), the count of service establishments in 1992 (SVC), and the count of manufacturing establishments in 1992 (MAN). All of these measures are at the zip code level. Greater market demand will increase revenue per room.

While these measures reflect the potential demand originating from residents in a market, another source of demand is highway traffic; a market may have high demand not only due to many residents, but also because the market is well located as an intermediate point from one major destination to another. While the number of automobiles passing through a zip code would be the ideal, after consulting with the Texas Department of Transportation, this measure is unavailable. Instead we use the number of gas stations in a market (GAS). These data are for 1992 and are zip code and quarter specific. Gas stations exist to serve both residents of and travelers passing through a market. Greater demand from non-residents should increase hotels' revenue performance.

For supply control variables, we use the count of similar competing hotels/motels in the market. Prior research by Baum and Mezias (1992) in the hotel industry shows that competition is localized-a hotel performance is more adversely affected when surrounded by similar hotels. This is because similar firms are more likely to compete for the same resources. Therefore instead of using the total count of competitors, which would be an undifferentiated measure, we use two count measures to capture presence of similar hotels. First is count of hotels that are of similar size (CNT_SMSZ). We categorize hotels into ten size classes (described later). If hotels are in the same size class, then we say they are of similar size. Second is the count of hotels that have the same chain affiliation 
(CNT_SMCHN); for a chain hotel this is the count of other chain hotels, for independents this is the count of other independents. Both CNT_SMCHN and CNT_SMSZ vary for each firm within a market. If a market has many large and few small hotels, then CNT_SMSZ is high if the focal hotel is large, but is low if the focal hotel is small. Similarly, if the market has many chains, then CNT_SMCHN is high if the focal hotel is a chain, but lower if the focal hotel is an independent. Greater market supply from similar sized and affiliated establishments will decrease a hotel's revenue per room.

More expensive, higher quality hotels will have greater revenue per room. We use two types of controls to capture hotels' quality. First, since firms build brands explicitly to signal quality, we account for whether or not the establishment is chain affiliated (CHAIN = 1 if chain affiliated). We determine affiliation by examining establishments' names and comparing them to a comprehensive hotel brand name list taken from Conlin (1999), which Conlin constructs by reviewing Lodging Hospitality, a trade magazine for the lodging industry. ${ }^{7}$ Following Ingram and Baum (1997), who show that chain affiliation increases an establishment's survival, chain affiliation should increase an establishment's revenue performance.

Second, we include size classes. Large hotels are typically more luxurious than small hotels and therefore will charge higher prices per room. They charge higher prices per room because they have more features. They have more features because facility enhancements require economies of scale-the ability to spread fixed costs across many units, which lowers per unit cost. For example, installing a swimming pool makes little sense for a hotel with 25 rooms, but is almost always present in a hotel of 200 rooms. Therefore, we include size class dummy variables (SIZE1 through SIZE10) where SIZE1 is 25-49 rooms, SIZE2 is 50-74 rooms, SIZE 3 is 75-99 rooms, etc.; SIZE10 is greater than 249 room. $^{8}$

We use dummy variables for size classes instead of using a continuous size measure for two reasons. First, our dependent variable is revenue performance-total revenues divided by size (indicated by the number of rooms). Therefore introducing a continuous measure of size on the right-hand-side as an independent variable would essentially be regressing a transformed value of size on itself, which artificially increases size's significance. ${ }^{9}$ Second, we suspect beyond just economies of scale that several levels of minimum efficient scale exist: a hotel must be of a minimum size to justify an exercise room; of a different size to justify a swimming pool; of yet other different sizes to justify an affiliated restaurant, ballrooms and meeting rooms. This suggests that the relationship between size and revenue per room is non-linear with several thresholds. Size class dummy variables allow such a relationship to emerge in a less constrained fashion than other specifications.

Beyond these two measures, we considered using the "star" ratings from the American Automobile Association (AAA) as reported in their widely popular tour books. Surprisingly, after collecting several past years' editions for Texas and coding the data, we found that the AAA tour books only cover $15 \%$ or less of all hotels in Texas. What decision criteria AAA uses to include or exclude hotels from their tour books is unclear. Not wanting to

\footnotetext{
${ }^{7}$ While Conlin's list spans hotel brands from 1991 through 1997, to ensure this list was comprehensive we further investigate when our data report more than five hotels with similar names. We searched back records in the Dow Jones News data base using these names combined with "brand" (or chain or franchise) and "hotel" (or motel) to determine whether these occurrences of similar names actually were chains. These searches did not reveal any additional hotel brands.

${ }^{8}$ Visual inspection suggests size breaks at twenty-five room increments. To support this increment we use PROC CLUSTER in SAS, which indicates breaks exist at twenty room increments on the low end and forty room increments on the high end. Instead of defining SIZE1 as 25 -44 (a 20 room increment), SIZE2 as $45-84$ (a 40 room increment), SIZE3 as 85-124 (a 30 room increment), etc.; we use fixed twenty-five room increments for definitional consistency.

${ }^{9}$ An ordinal transformation of size as an independent variable would still have the same problem, as would higher order quadratic terms.
} 
use a sampling frame with an unknown bias and knowing that size class replicates much of the same information (the correlation between AAA stars and size is very high for this overlapping $15 \%$ of observations), we omitted these star ratings.

We also include whether the hotel is headquartered outside of Texas (DIST_HQ = 1 if the owner location is outside of Texas). The effect can be either positive or negative. It may signal expansion of a strong competitor from out-of-state markets, or distant owners that are more subject to agency problems. While the revenue performance implications are unclear, DIST_HQ is another potential control for quality, either good or bad.

Finally, corresponding to the hypotheses, we have two agglomeration measures. First is the fraction of chain affiliated firms (FRA_HAIN). This fraction can be based upon either the count of competitors or the count of rooms in the market and are highly correlated; the results reported subsequently are based upon count of competitors, though results are materially the same using either. The second measure is the fraction of firms in the market that are larger (greater in size) than the focal hotel (FRA_GTSZ). While FRA_HAIN is market invariant_the same for all hotels in a given market, FRA_GTSZ varies for each hotel in a market. For the largest hotel in a market, FRA_GTSZ is zero-the fraction of hotels of greater size in the market is zero; while for the smallest hotel, FRA_GTSZ is equal to one. More chain affiliated and larger firms should contribute to demand agglomeration benefits.

We use fractions to capture agglomeration effects because we need measures that reflect the composition of firms in the market, but that are not counts, since counts are used to capture competition. An additional benefit is the correlation between the count and fraction measures of size; FRA_GTSZ and CNTSMSZ are correlated by construction, which we can take advantage of empirically. These variables correlation provides an empirical opportunity, in that when two variables are correlated the variables' statistical power comes from the portion of their variance that does not co-vary. The portion of their variance that is perfectly correlated is essentially lost and the resulting coefficient estimates are based upon each measure's unique variance. While CNT_SMSZ captures competition, FRA_GTSZ capture something other than competition as the portion of FRA_GTSZ variance that is perfectly correlated with CNT_SMSZ is lost. Thus, FRA_GTSZ captures an effect of other firms' presence that is not competition; this leaves agglomeration effects (and other residual explanations).

Some descriptive information for the largest twenty chains in Texas is included as Table 1. Comparing chains to independent hotels, independents are generally smaller-especially in rural areas and have lower revenues per room. Looking across lodging chains, Table 1 shows that some chains-such as Best Western, Econo Lodge, and Travel Lodge avoid urban and suburban locations in favor of rural markets.

To better understand location patterns, we plot where chain affiliated hotels locate. Figure 1 shows all hotels. Figure 2 shows FRA_HAIN, fraction of chain affiliated hotels. The plots are by county (174 counties) since the plots by zip codes (487 zip codes) are too small to be legible.

Unsurprisingly, there are more hotels in urban locations and along interstate highways. Chain hotels also appear to concentrate in urban areas and along highways.

\section{METHOD AND RESULTS}

To determine whether demand agglomeration gains exist and who contributes to them, we regress a hotel's 
revenue per room on its market demand and supply conditions, the hotel's own traits, and the market-level agglomeration measures. We use ordinary least squares-OLS regressions with two-way fixed effects. Fixed effects are required because we pool across time and across markets. Therefore we include 3 quarterly dummies (pooling four quarters only requires three quarterly dummies since the remaining quarter is the base case) and 173 county dummies. The county-level dummy variables account for any unobserved, time invariant, regional influences that might alter

Table 1. Top 20 Texas lodging chains (based on four pooled quarters of 1992 data)

\begin{tabular}{|c|c|c|c|c|c|}
\hline & & $\begin{array}{l}\text { No. of } \\
\text { hotels }\end{array}$ & $\begin{array}{l}\text { Avg no. } \\
\text { rooms }\end{array}$ & $\begin{array}{l}\text { Avg. } \\
\text { rev./room }\end{array}$ & $\begin{array}{l}\text { Sub. and urban } \\
\text { location }\end{array}$ \\
\hline 1 & Motel 6 & 67 & 111 & $\$ 1882$ & $25.4 \%$ \\
\hline 2 & Holiday Inn & 38 & 206 & $\$ 2673$ & $28.1 \%$ \\
\hline 3 & Best Westem & 37 & 88 & $\$ 2088$ & $8.7 \%$ \\
\hline 4 & Days Inn & 33 & 117 & $\$ 1368$ & $27.3 \%$ \\
\hline 5 & La Quinta & 20 & 121 & $\$ 2677$ & $46.2 \%$ \\
\hline 6 & Econo Lodge & 17 & 82 & $\$ 1323$ & $7.2 \%$ \\
\hline 7 & Ramada Inn & 14 & 147 & $\$ 2133$ & $47.4 \%$ \\
\hline 8 & Comfort Inn & 14 & 69 & $\$ 1805$ & $0.0 \%$ \\
\hline 9 & Hilton & 11 & 238 & $\$ 2890$ & $22.7 \%$ \\
\hline 10 & Super 8 & 10 & 76 & $\$ 1820$ & $30.0 \%$ \\
\hline 11 & Quality Inn & 8 & 134 & $\$ 1840$ & $21.2 \%$ \\
\hline 12 & Rodeway Inn & 8 & 87 & $\$ 1984$ & $60.6 \%$ \\
\hline 13 & Travel Lodge & 8 & 86 & $\$ 1615$ & $12.1 \%$ \\
\hline 14 & Red Roof Inn & 8 & 134 & $\$ 1955$ & $25.0 \%$ \\
\hline 15 & Sheraton & 8 & 203 & $\$ 4355$ & $53.1 \%$ \\
\hline 16 & Drury Inn & 7 & 122 & $\$ 3443$ & $71.4 \%$ \\
\hline 17 & Hampton Inn & 7 & 120 & $\$ 3582$ & $28.6 \%$ \\
\hline 18 & Howard Johnson & 7 & 113 & $\$ 1558$ & $46.2 \%$ \\
\hline 19 & Radisson & 5 & 239 & $\$ 3706$ & $40.0 \%$ \\
\hline \multirow[t]{5}{*}{20} & Hawthom Suites & 5 & 110 & $\$ 5139$ & $66.7 \%$ \\
\hline & Average CHAIN & 332 & 128 & $\$ 2192$ & $27.5 \%$ \\
\hline & Sub. and urban independents & 206 & 84 & $\$ 1415$ & $100.0 \%$ \\
\hline & Rural independents & 585 & 65 & $\$ 1259$ & $0.0 \%$ \\
\hline & Average Independent & 791 & 70 & $\$ 1299$ & $26.1 \%$ \\
\hline
\end{tabular}




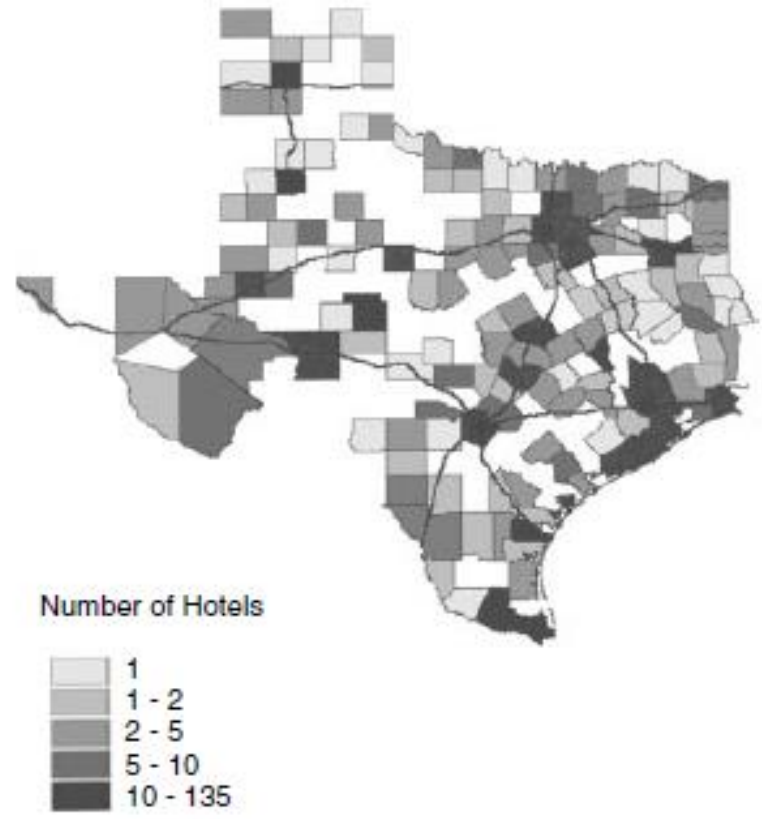

Figure 1. Location of Hotels. Hotel location shown by county

revenue performance. For example, those zip code quarterly dummy variables capture any seasonality. Demand for hotel services easily might be greater in the summer than in the winter.

Importantly, we use only one observation per zip code-quarter. We do so to prevent violating OLS ideal conditions of a spherical disturbance-that observations have the same, constant disturbance variance and that all possible pairs of disturbance covariance are zero. The revenues of hotels in the same market are clearly not independent, which is the point of this paper. For example, in a market with two hotels, the performance of hotel $A$ is integrally linked to the performance of hotel B. Gains for A will often be at the expense of B if competition dominates or gains for $A$ and $B$ will be positively linked if demand agglomeration dominates. While we include two agglomeration measures and several competition measures, these variables may not fully capture all possible dimensions of agglomeration and competition. When variables are not explicitly included as independent variables, they become implicitly included in the disturbance/error structure. ${ }^{10}$ Since we cannot definitively state that we have included all possible agglomeration and competition measures, the disturbance matrix is likely non-spherical when multiple observations from the same market are included. Specifically, while a spherical disturbance is a square

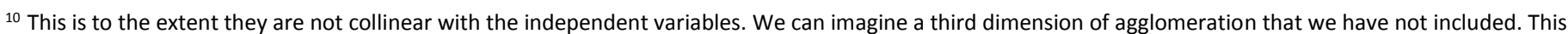

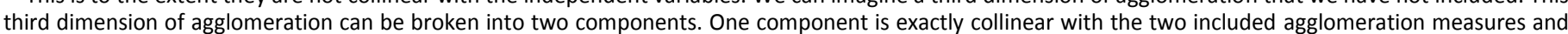

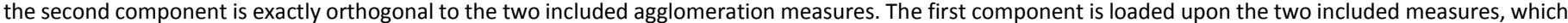
overstates their importance. The second component remains a part of the disturbance/error structure.
} 
matrix with a diagonal of constant non-zero values and an off-diagonal of all zeros; the covariance of any two observations from the same zip-quarter is likely non-zero. Observations from the same zip code market are likely not independent. This violation of ideal conditions either increases or decreases standard errors in a non-predictable fashion that renders hypothesis testing unreliable.

Obvious approaches such as including zip code fixed effects and weighting observations do not address this potential lack of independence. A zip code dummy provides a common offset for all hotels in a zip code, which does not address that the observations are dependent. Scaling or weighting observations transforms the diagonal and offdiagonal elements, but does not change non-zero off-diagonal elements to zero. While using Generalized Least Squares can address the lack of independence, GLS requires that we make assumptions about the structure of the disturbance. This structure can easily be different in each zip code market and incorrect assumptions would call our statistical results into question. ${ }^{11}$ Therefore to maintain a spherical disturbance matrix, we use only a single observation per zip code market-while two observations from the same market are likely not independent, two observations from separate markets likely are.

A single observation per zip code-quarter is randomly selected which leaves 1,881 observations for subsequent statistical analysis. We draw several random samples and each sample provides results qualitatively similar to those reported below in coefficient sign, magnitude, and significance. Descriptive statistics for the 1,881 observations are shown below in Table 2; the nine size class dummy variables are omitted in the interest of space.

We investigate "who contributes to agglomeration demand effects?" in Table 3. Table 3 incrementally adds categories of variables until the full specification is achieved. Variables are added incrementally to observe the stability of control variables. Columns 1, 2, and 3 incrementally introduce control variables for demand, supply, and establishment traits. Column 4 is the full specification. Table 3's coefficient estimates indicate the revenue per room a hotel earns in a fiscal quarter. Therefore a positive coefficient estimate of 100 indicates a hotel earns $\$ 100.00$ more a quarter per room if that variable's value is equal to one.

Looking across the first four columns, of the numerous control variables only a few are significant. For the demand controls the count of retail (RET) and service establishments (SVC) are intermittently significant while per capita income $(\mathrm{PCl})$ is consistently so; their positive coefficients suggest that services positively compliment hotels and that higher income markets offer higher revenues.

For supply, the count of same size and same chain affiliation (CNT_SMSZ and CNT_SMCHN) are negative and intermittently significant if using a 10\% 1-tailed test, as expected. More similar competitors reduce a hotel's revenue performance. These estimates are somewhat consistent with Baum and Mezias (1992) who argue that firms that are similar in size compete more vigorously.

For establishment traits, chain affiliated hotels (CHAIN) have greater revenue performance. This is consistent with chain brands signaling unobservable quality that allows higher prices and is also consistent with higher occupancy achieved through chain wide reservation systems. The coefficient estimate attracted by CHAIN in column 4 is 803.01 , which suggests that chain affiliated hotels earn $\$ 803.01$ more per room each quarter. Finally, several size

\footnotetext{
${ }^{11}$ For robustness, we do include a random-effect specification for the 487 zip codes while using all observations. These results are similar to those obtained from using OLS with random samples. We discuss this alternate specification later in the "checks" section.
} 
dummies are significant in three intermittent ranges (SIZE2: 50-75 rooms; SIZE5, 6, and 7: 125-200 rooms; SIZE 9 and 10: greater than 225 rooms). These intermittent ranges are consistent with scale economies for different types of facility improvements; a hotel needs to be of a certain size to justify the fixed cost of a workout room, a swimming pool, ballrooms, and an affiliated restaurant.

For the two variables of interest-the agglomeration effects-one has significant influence. The fraction of establishments in the market that are greater in size than the focal establishment (FRA_GTSZ) is significantly positive. This is consistent with the expectation of larger hotels being able to afford advertising since this fixed cost is spread over more rooms. Advertising, as a signal to consumers, reduces consumers' search costs; the more collacted hotels that are signaling increases the number of consumers who visit that particular location. Advertising may be via television and/or print, or be as simple as large signs readily visible from a distance. The coefficient suggests that for a $10 \%$ increase in larger establishments present in a market, that other hotels' revenue per room increases by $\$ 71.39$ per fiscal quarter.

To further investigate who contributes to agglomeration effects, we split our sample by type of marketwhether a market is rural versus suburban/urban. ${ }^{12}$ The results for the rural versus (sub)urban split samples are reported in columns 5 and 6 . For urban and suburban markets in column 6 , neither of the agglomeration variables is significantly different from zero. In contrast, for rural markets in column 5, the coefficients for FRA_GTSZ remain significant and of similar magnitude to column 4, even with a $25 \%$ decrease in observations (1407 versus 1881). The results in columns 5 and 6 clearly support Hypothesis 3 that agglomeration benefits are more likely to be present in rural than in urban areas.

Overall, the results in Table 3 indicate who contributes to agglomeration demand effects-how the composition of competitors in a market affects all establishments in the same market. We find that a hotel experiences better revenue performance when its market contains more hotels that are larger than itself. This finding supports Hypothesis 1a. Given this preliminary evidence that agglomeration demand gains exist, we turn to the second question of who gains from such agglomeration effects.

To answer "who gains from agglomeration?" we introduce two interaction variables. We interact the two hotel traits - chain affiliation (CHAIN) and establishment size (size dummies) each with the corresponding market agglomeration measure - fraction of chain (FRA_HAIN) and fraction of larger hotels in a market (FRA_GTSZ). For the interactions with size class dummy variables, we group the nine variables (SIZE2, SIZE3, SIZE4... SIZE10) into three ranges to keep the number of interactions manageable: 1 to 3, 4 to 7, and 8 to 10. For example, SIZE4567 *FRA_HAIN includes SIZE4, SIZE5, SIZE6, and SIZE7 interacted with CHAIN. Positive coefficients attracted by these interaction variables indicate what type of firm gains from agglomeration.

\footnotetext{
12 We use PROC CLUSTER in SAS with density (population per square mile) as the cluster criteria. The clustering procedure maximizes between group variation while minimizing within group variation. Initially we ask for three clusters that would correspond to rural, suburban, and urban; but find that one or two superurban markets (density of greater than 4,400 people per square mile) consumed the urban cluster. We iterated the number of clusters upwards from three, to four, to five, and to six. Additional incremental clusters refined the divisions between suburban, urban, and super-urban markets (more super-urban clusters were added), but did not change the split between rural and suburban-the definition of rural stayed constant. Therefore we adopt this split between rural and suburban of 975 people per square mile. While 975 seems high, using this split, the average for markets defined as rural is only 113 people per square mile.
} 
Table 2. Descriptive statistics

\begin{tabular}{|c|c|c|c|c|c|c|c|c|c|c|c|c|c|c|c|c|}
\hline & & 1 & 2 & 3 & 4 & 5 & 6 & 7 & 8 & 9 & 10 & 11 & 12 & 13 & 14 & 15 \\
\hline 1 & REV_PER & $\begin{array}{l}1.000 \\
0.00\end{array}$ & $\begin{array}{l}0.101 \\
0.00\end{array}$ & $\begin{array}{l}0.280 \\
0.00\end{array}$ & $\begin{array}{c}-0.094 \\
0.00\end{array}$ & $\begin{array}{l}0.138 \\
0.00\end{array}$ & $\begin{array}{l}0.194 \\
0.00\end{array}$ & $\begin{array}{l}0.265 \\
0.00\end{array}$ & $\begin{array}{l}0.124 \\
0.00\end{array}$ & $\begin{array}{l}0.052 \\
0.02\end{array}$ & $\begin{array}{c}-0.058 \\
0.01\end{array}$ & $\begin{array}{c}-0.013 \\
0.56\end{array}$ & $\begin{array}{l}0.278 \\
0.00\end{array}$ & $\begin{array}{l}0.104 \\
0.00\end{array}$ & $\begin{array}{l}0.253 \\
0.00\end{array}$ & $\begin{array}{l}0.013 \\
0.56\end{array}$ \\
\hline 2 & POP & $\begin{array}{l}0.101 \\
0.00\end{array}$ & $\begin{array}{l}1.000 \\
0.00\end{array}$ & $\begin{array}{l}0.056 \\
0.01\end{array}$ & $\begin{array}{c}-0.189 \\
0.00\end{array}$ & $\begin{array}{l}0.947 \\
0.00\end{array}$ & $\begin{array}{l}0.664 \\
0.00\end{array}$ & $\begin{array}{l}0.407 \\
0.00\end{array}$ & $\begin{array}{l}0.356 \\
0.00\end{array}$ & $\begin{array}{l}0.650 \\
0.00\end{array}$ & $\begin{array}{l}0.139 \\
0.00\end{array}$ & $\begin{array}{l}0.255 \\
0.00\end{array}$ & $\begin{array}{l}0.092 \\
0.00\end{array}$ & $\begin{array}{l}0.075 \\
0.00\end{array}$ & $\begin{array}{l}0.148 \\
0.00\end{array}$ & $\begin{array}{l}0.211 \\
0.00\end{array}$ \\
\hline 3 & $\mathrm{PCI}$ & $\begin{array}{l}0.280 \\
0.00\end{array}$ & $\begin{array}{l}0.056 \\
0.01\end{array}$ & $\begin{array}{l}1.000 \\
0.00\end{array}$ & $\begin{array}{c}-0.201 \\
0.00\end{array}$ & $\begin{array}{l}0.188 \\
0.00\end{array}$ & $\begin{array}{l}0.241 \\
0.00\end{array}$ & $\begin{array}{l}0.476 \\
0.00\end{array}$ & $\begin{array}{l}0.101 \\
0.00\end{array}$ & $\begin{array}{l}0.036 \\
0.12\end{array}$ & $\begin{array}{c}-0.083 \\
0.00\end{array}$ & $\begin{array}{c}-0.056 \\
0.02\end{array}$ & $\begin{array}{l}0.186 \\
0.00\end{array}$ & $\begin{array}{l}0.069 \\
0.00\end{array}$ & $\begin{array}{l}0.207 \\
0.00\end{array}$ & $\begin{array}{c}-0.040 \\
0.08\end{array}$ \\
\hline 4 & LAND & $\begin{array}{c}-0.094 \\
0.00\end{array}$ & $\begin{array}{c}-0.189 \\
0.00\end{array}$ & $\begin{array}{c}-0.201 \\
0.00\end{array}$ & $\begin{array}{l}1.000 \\
0.00\end{array}$ & $\begin{array}{c}-0.218 \\
0.00\end{array}$ & $\begin{array}{c}-0.189 \\
0.00\end{array}$ & $\begin{array}{c}-0.262 \\
0.00\end{array}$ & $\begin{array}{c}-0.221 \\
0.00\end{array}$ & $\begin{array}{c}-0.028 \\
0.23\end{array}$ & $\begin{array}{l}0.068 \\
0.00\end{array}$ & $\begin{array}{l}0.011 \\
0.65\end{array}$ & $\begin{array}{c}-0.124 \\
0.00\end{array}$ & $\begin{array}{c}-0.074 \\
0.00\end{array}$ & $\begin{array}{c}-0.163 \\
0.00\end{array}$ & $\begin{array}{c}-0.001 \\
0.96\end{array}$ \\
\hline 5 & HOMES & $\begin{array}{l}0.138 \\
0.00\end{array}$ & $\begin{array}{l}0.947 \\
0.00\end{array}$ & $\begin{array}{l}0.188 \\
0.00\end{array}$ & $\begin{array}{c}-0.218 \\
0.00\end{array}$ & $\begin{array}{l}1.000 \\
0.00\end{array}$ & $\begin{array}{l}0.701 \\
0.00\end{array}$ & & $\begin{array}{l}0.379 \\
0.00\end{array}$ & $\begin{array}{l}0.631 \\
0.00\end{array}$ & $\begin{array}{l}0.132 \\
0.00\end{array}$ & $\begin{array}{l}0.255 \\
0.00\end{array}$ & $\begin{array}{l}0.106 \\
0.00\end{array}$ & $\begin{array}{l}0.115 \\
0.00\end{array}$ & $\begin{array}{l}0.160 \\
0.00\end{array}$ & $\begin{array}{l}0.209 \\
0.00\end{array}$ \\
\hline 6 & RET & $\begin{array}{l}0.194 \\
0.00\end{array}$ & $\begin{array}{l}0.664 \\
0.00\end{array}$ & $\begin{array}{l}0.241 \\
0.00\end{array}$ & $\begin{array}{c}-0.189 \\
0.00\end{array}$ & $\begin{array}{l}0.701 \\
0.00\end{array}$ & $\begin{array}{l}1.000 \\
0.00\end{array}$ & & & & $\begin{array}{l}0.213 \\
0.00\end{array}$ & & & $\begin{array}{l}0.102 \\
0.00\end{array}$ & $\begin{array}{l}0.266 \\
0.00\end{array}$ & $\begin{array}{l}0.292 \\
0.00\end{array}$ \\
\hline 7 & SVC & $\begin{array}{l}0.265 \\
0.00\end{array}$ & $\begin{array}{l}0.407 \\
0.00\end{array}$ & $\begin{array}{l}0.476 \\
0.00\end{array}$ & $\begin{array}{c}-0.262 \\
0.00\end{array}$ & $\begin{array}{l}0.504 \\
0.00\end{array}$ & $\begin{array}{l}0.728 \\
0.00\end{array}$ & $\begin{array}{l}1.000 \\
0.00\end{array}$ & $\begin{array}{l}0.509 \\
0.00\end{array}$ & $\begin{array}{l}0.419 \\
0.00\end{array}$ & $\begin{array}{l}0.075 \\
0.00\end{array}$ & $\begin{array}{l}0.212 \\
0.00\end{array}$ & $\begin{array}{l}0.193 \\
0.00\end{array}$ & $\begin{array}{l}0.119 \\
0.00\end{array}$ & $\begin{array}{l}0.276 \\
0.00\end{array}$ & $\begin{array}{l}0.177 \\
0.00\end{array}$ \\
\hline 8 & MAN & $\begin{array}{l}0.124 \\
0.00\end{array}$ & $\begin{array}{l}0.356 \\
0.00\end{array}$ & $\begin{array}{l}0.101 \\
0.00\end{array}$ & $\begin{array}{c}-0.221 \\
0.00\end{array}$ & $\begin{array}{l}0.379 \\
0.00\end{array}$ & $\begin{array}{l}0.468 \\
0.00\end{array}$ & $\begin{array}{l}0.509 \\
0.00\end{array}$ & $\begin{array}{l}1.000 \\
0.00\end{array}$ & $\begin{array}{l}0.398 \\
0.00\end{array}$ & $\begin{array}{l}0.007 \\
0.75\end{array}$ & $\begin{array}{l}0.114 \\
0.00\end{array}$ & $\begin{array}{l}0.146 \\
0.00\end{array}$ & $\begin{array}{l}0.122 \\
0.00\end{array}$ & $\begin{array}{l}0.233 \\
0.00\end{array}$ & $\begin{array}{l}0.170 \\
0.00\end{array}$ \\
\hline 10 & CNT_SMSZ & $\begin{array}{c}0.052 \\
0.02 \\
-0.058 \\
0.01\end{array}$ & $\begin{array}{l}0.650 \\
0.00 \\
0.139 \\
0.00\end{array}$ & $\begin{array}{c}0.036 \\
0.12 \\
-0.083 \\
0.00\end{array}$ & $\begin{array}{c}-0.028 \\
0.23 \\
0.068 \\
0.00\end{array}$ & $\begin{array}{l}0.631 \\
0.00 \\
0.132 \\
0.00\end{array}$ & $\begin{array}{l}0.664 \\
0.00 \\
0.213 \\
0.00\end{array}$ & $\begin{array}{l}0.419 \\
0.00 \\
0.075 \\
0.00\end{array}$ & $\begin{array}{l}0.398 \\
0.00 \\
0.007 \\
0.75\end{array}$ & $\begin{array}{l}1.000 \\
0.00 \\
0.188 \\
0.00\end{array}$ & $\begin{array}{l}0.188 \\
0.00 \\
1.000 \\
0.00\end{array}$ & $\begin{array}{l}0.329 \\
0.00 \\
0.633 \\
0.00\end{array}$ & $\begin{array}{c}0.076 \\
0.00 \\
-0.057 \\
0.01\end{array}$ & $\begin{array}{c}0.059 \\
0.01 \\
-0.029 \\
0.021\end{array}$ & $\begin{array}{c}0.152 \\
0.00 \\
-0.009 \\
0.68\end{array}$ & $\begin{array}{l}0.270 \\
0.00 \\
0.143 \\
0.00\end{array}$ \\
\hline 11 & CNT_SMCHN & $\begin{array}{c}-0.013 \\
0.56\end{array}$ & $\begin{array}{l}0.255 \\
0.00\end{array}$ & $\begin{array}{c}-0.056 \\
0.02\end{array}$ & $\begin{array}{l}0.011 \\
0.65\end{array}$ & $\begin{array}{l}0.255 \\
0.00\end{array}$ & $\begin{array}{l}0.399 \\
0.00\end{array}$ & $\begin{array}{l}0.212 \\
0.00\end{array}$ & $\begin{array}{l}0.114 \\
0.00\end{array}$ & $\begin{array}{l}0.329 \\
0.00\end{array}$ & $\begin{array}{l}0.633 \\
0.00\end{array}$ & $\begin{array}{l}1.000 \\
0.00\end{array}$ & $\begin{array}{r}-0.08 \\
0.00\end{array}$ & $\begin{array}{c}-0.008 \\
0.74\end{array}$ & $\begin{array}{l}0.004 \\
0.87\end{array}$ & $\begin{array}{l}0.437 \\
0.00\end{array}$ \\
\hline 12 & CHAIN & $\begin{array}{l}0.278 \\
0.00\end{array}$ & $\begin{array}{l}0.092 \\
0.00\end{array}$ & $\begin{array}{l}0.186 \\
0.00\end{array}$ & $\begin{array}{c}-0.124 \\
0.00\end{array}$ & $\begin{array}{l}0.106 \\
0.00\end{array}$ & $\begin{array}{l}0.173 \\
0.00\end{array}$ & $\begin{array}{l}0.193 \\
0.00\end{array}$ & $\begin{array}{l}0.146 \\
0.00\end{array}$ & $\begin{array}{l}0.076 \\
0.00\end{array}$ & $\begin{array}{c}-0.057 \\
0.01\end{array}$ & $\begin{array}{r}-0.08 \\
0.00\end{array}$ & $\begin{array}{l}1.000 \\
0.00\end{array}$ & $\begin{array}{l}0.166 \\
0.00\end{array}$ & $\begin{array}{l}0.810 \\
0.00\end{array}$ & $\begin{array}{c}-0.051 \\
0.03\end{array}$ \\
\hline 13 & DIST_HQ & $\begin{array}{l}0.104 \\
0.00\end{array}$ & $\begin{array}{l}0.075 \\
0.00\end{array}$ & $\begin{array}{l}0.069 \\
0.00\end{array}$ & $\begin{array}{c}-0.074 \\
0.00\end{array}$ & $\begin{array}{l}0.115 \\
0.00\end{array}$ & $\begin{array}{l}0.102 \\
0.00\end{array}$ & $\begin{array}{l}0.119 \\
0.00\end{array}$ & $\begin{array}{l}0.122 \\
0.00\end{array}$ & $\begin{array}{l}0.059 \\
0.01\end{array}$ & $\begin{array}{c}-0.029 \\
0.21\end{array}$ & $\begin{array}{c}-0.008 \\
0.74\end{array}$ & $\begin{array}{l}0.166 \\
0.00\end{array}$ & $\begin{array}{l}1.000 \\
0.00\end{array}$ & $\begin{array}{l}0.168 \\
0.00\end{array}$ & $\begin{array}{c}-0.075 \\
0.00\end{array}$ \\
\hline 14 & FRA_HAIN & $\begin{array}{l}0.253 \\
0.00\end{array}$ & $\begin{array}{l}0.148 \\
0.00\end{array}$ & $\begin{array}{l}0.207 \\
0.00\end{array}$ & $\begin{array}{c}-0.163 \\
0.00\end{array}$ & $\begin{array}{l}0.160 \\
0.00\end{array}$ & $\begin{array}{l}0.266 \\
0.00\end{array}$ & $\begin{array}{l}0.276 \\
0.00\end{array}$ & $\begin{array}{l}0.233 \\
0.00\end{array}$ & $\begin{array}{l}0.152 \\
0.00\end{array}$ & $\begin{array}{c}-0.009 \\
0.68\end{array}$ & $\begin{array}{l}0.004 \\
0.87\end{array}$ & $\begin{array}{l}0.810 \\
0.00\end{array}$ & $\begin{array}{l}0.168 \\
0.00\end{array}$ & $\begin{array}{l}1.000 \\
0.00\end{array}$ & $\begin{array}{l}0.187 \\
0.00\end{array}$ \\
\hline 15 & FRA_GTSZ & $\begin{array}{l}0.013 \\
0.56\end{array}$ & $\begin{array}{l}0.211 \\
0.00\end{array}$ & $\begin{array}{c}-0.040 \\
0.08\end{array}$ & $\begin{array}{c}-0.001 \\
0.96\end{array}$ & $\begin{array}{l}0.209 \\
0.00\end{array}$ & $\begin{array}{l}0.292 \\
0.00\end{array}$ & $\begin{array}{l}0.177 \\
0.00\end{array}$ & $\begin{array}{l}0.170 \\
0.00\end{array}$ & $\begin{array}{l}0.270 \\
0.00\end{array}$ & $\begin{array}{l}0.143 \\
0.00\end{array}$ & $\begin{array}{l}0.437 \\
0.00\end{array}$ & $\begin{array}{c}-0.051 \\
0.03\end{array}$ & $\begin{array}{c}-0.075 \\
0.00\end{array}$ & $\begin{array}{l}0.187 \\
0.00\end{array}$ & $\begin{array}{l}1.000 \\
0.00\end{array}$ \\
\hline & $\begin{array}{l}n \\
\text { Mean }\end{array}$ & $\begin{array}{l}1881 \\
1682\end{array}$ & $\begin{array}{r}1881 \\
20024\end{array}$ & $\begin{array}{r}1881 \\
12466\end{array}$ & $\begin{array}{r}1881 \\
437\end{array}$ & $\begin{array}{l}1881 \\
8454\end{array}$ & $\begin{array}{r}1881 \\
136\end{array}$ & $\begin{array}{r}1881 \\
173\end{array}$ & $\begin{array}{c}1881 \\
26.5\end{array}$ & $\begin{array}{l}1881 \\
8.71 \\
58\end{array}$ & $\begin{array}{l}1881 \\
1.43\end{array}$ & $\begin{array}{l}1881 \\
0.900\end{array}$ & & & $\begin{array}{l}1881 \\
0.328\end{array}$ & $\begin{array}{l}1881 \\
0.113 \\
0.21\end{array}$ \\
\hline & S.D. & 2073 & 13129 & 6034 & 793 & 5468 & 112 & 182 & 28.6 & 5.80 & 0.80 & 1.420 & 0.457 & 0.306 & 0.399 & 0.211 \\
\hline
\end{tabular}


Table 3. Determinants of revenue per room

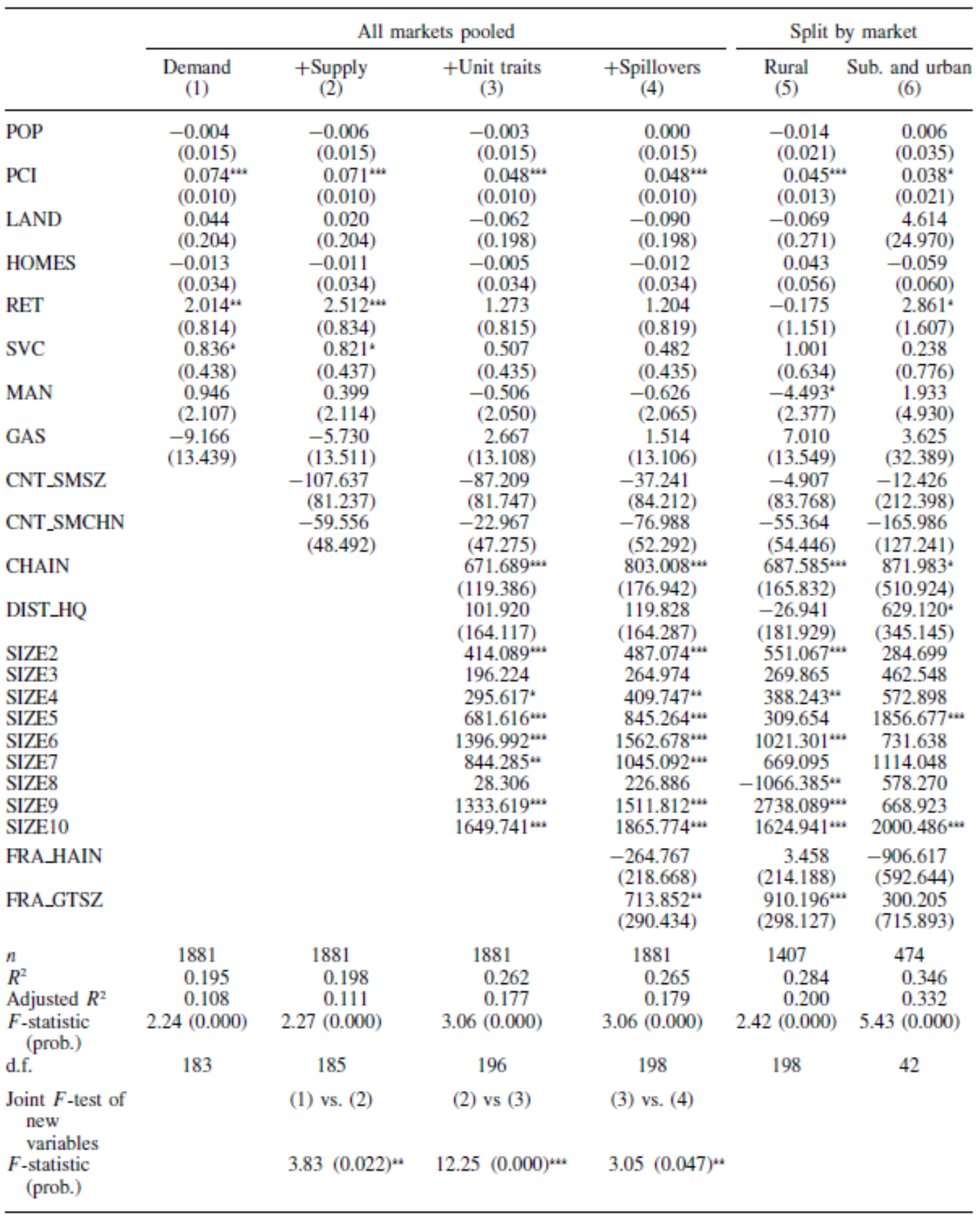

Standard errors in parentheses.

Not shown: 3 quarterly and 173 county dummies (13 dummies in model 6 only for urban markets). 
When analyzing who gains from demand agglomeration, we use only rural markets since the results from Table 3 -columns 5 and 6 , indicate that demand agglomeration effects are strongly present in rural markets. The results of introducing the interaction terms are shown on Table 4.

Table 4 has two sets of three columns; the two sets use different model specifications. The main results are presented in the first set of three columns, while the second set are another specification to check the robustness of the first set of results. For now, we focus on the first set of columns. The first column simply replicates the results from column 5 of Table 3 and acts as a baseline reference for the other specifications that include the interaction terms. Column 2 introduces the interaction of CHAIN and FRA_HAIN. Column 3 then introduces the interaction variables for the size class dummy variables.

Looking at column 2, both the chain interaction variable (CHAIN*FRA_HAIN) and (CHAIN) are significant. In comparison, CHAIN was not significant in column 1. Wary that the significance of both CHAIN*FRA_HAIN and CHAIN result from collinearity, when the presence of correlated variables causes an insignificant variable to appear significant since standard errors can shrink; we conduct an F-test comparing the change in model fit between columns 1 and 2. This F-test is reported at the bottom of column 2 and shows that including CHAIN*FRA_HAIN significantly improves model fit - that this inclusion describes the data better and therefore the significance of CHAIN*FRA_HAIN and CHAIN are not the result of multicollinearity. Note that including this interaction term results in support for Hypothesis $1 \mathrm{~b}$; the more chain affiliated firms in a market, the greater the agglomeration benefits.

The coefficient on the interaction effect is negative (-1483.41) and positive on the main effect (611.49). Together they suggest independent hotels gain by having more chains in the market, while chain hotels are harmed. For a $10 \%$ increase in fraction of chains, the independent sees $\$ 61.15$ more per quarter per room, while a chain sees $\$ 87.19$ less $(0.1 *(-1484.31+611.49))$. Figure 3 shows the combined effect of CHAIN *FRA_HAIN and its two component variables, CHAIN and FRA_HAIN. We see that independents obtain positive agglomeration effects, while chains experience negative effects. These negative effects are beyond competitive effects already reflected by the count of chain hotels in the market. Potentially, hotels' ability to influence composition of customers through their signaling is limited in rural markets. Say customers traveling rural interstates are typically composed 50/50 of those preferring chains versus independents. In a location that is $60 \%$ chains, the chains present may be able to alter the composition of customers visiting more to their favor, but a location that is almost totally chains may not be able to alter the mix sufficiently. As a market has more chains, the ability to get the same portion or more of customers preferring chains drops, which might causes this negative effect.

While this negative agglomeration effect among chains is high, Figure 3 shows that being a chain confers sufficient benefits such that chains do better across almost the entire range of FRA_HAIN, the fraction of chains hotels in a market, than nonchains.

Column 3 introduces the two size class interaction variables (SIZE4567 *FRA_GTSZ, SIZE890 *FRA_GTSZ) which both attract significant coefficient estimates. Again cautious of multicollinearity causing statistical significance to be overstated, we conduct an F-test for the change in model fit resulting from these additional variables. The Ftest, which is reported at the bottom of column 3 , shows that these size interactions significantly improve model fit. 
Table 4. Determinants of revenue per room with interaction effects

\begin{tabular}{|c|c|c|c|c|c|c|}
\hline & \multicolumn{3}{|c|}{$\begin{array}{l}\text { OLS using random sampling } \\
\text { One observation per zip code }\end{array}$} & \multicolumn{3}{|c|}{$\begin{array}{l}\text { GLS using full sample } \\
\text { Random effects for zip codes }\end{array}$} \\
\hline & $\begin{array}{l}\text { Baseline } \\
\text { (1) }\end{array}$ & $\begin{array}{l}\text { +Chain } \\
\text { (2) }\end{array}$ & $\begin{array}{l}+ \text { Size } \\
(3)\end{array}$ & $\begin{array}{l}\text { Baseline } \\
\text { (4) }\end{array}$ & $\begin{array}{l}\text { +Chain } \\
\text { (5) }\end{array}$ & $\begin{array}{c}+ \text { Size } \\
(6)\end{array}$ \\
\hline POP & -0.014 & -0.007 & -0.008 & 0.002 & 0.007 & 0.006 \\
\hline $\mathrm{PCI}$ & $0.045^{\mathrm{k}}$ & $0.050^{\ldots}$ & $0.045^{\omega}$ & $0.036^{\mathrm{kn}}$ & $0.041^{w \alpha}$ & $0.040^{* 2}$ \\
\hline LAND & -0.069 & -0.023 & 0.002 & 0.040 & 0.025 & 0.026 \\
\hline HOMES & 0.043 & 0.022 & 0.020 & -0.009 & -0.020 & -0.023 \\
\hline RET & -0.175 & -0.324 & 0.025 & 1.153 & 0.721 & 0.756 \\
\hline SVC & 1.001 & 1.037 & 0.868 & 0.708 & 0.763 & 0.759 \\
\hline MAN & $-4.493^{\circ}$ & $-4.921^{*}$ & -3.861 & -0.305 & -0.288 & 0.218 \\
\hline GAS & 7.010 & 6.640 & 2.782 & $-23.260^{\mathrm{n}}$ & $-24.362^{\cdots}$ & $-25.023^{\omega}$ \\
\hline CNT_SMSZ & -4.907 & -94.560 & -100.782 & -27.607 & $-69.777^{*}$ & $-67.697^{*}$ \\
\hline CNT_SMCHN & -55.364 & 2.159 & 12.149 & $-56.963^{\cdots}$ & -6.846 & -6.708 \\
\hline CHAIN & $687.585^{n *}$ & $1530.291^{* *}$ & $1550.159^{* 2}$ & $513.754^{* *}$ & $1162.947^{\omega *}$ & $1159.359^{* *}$ \\
\hline DIST_HQ & -26.941 & -72.321 & -124.078 & $153.089^{*}$ & 148.960 & 124.455 \\
\hline SIZE2 & $551.067^{\mathrm{kn}}$ & $454.802^{* *}$ & $489.212^{\omega}$ & $579.270^{\mathrm{kn}}$ & $506.399 \cdots$ & $517.061^{*}$ \\
\hline SIZE3 & 269.865 & 159.964 & 199.444 & $324.710^{* n}$ & $253.816^{4 *}$ & $256.775^{*}$ \\
\hline SIZE4 & $388.243^{*}$ & $303.194^{*}$ & $483.663^{*}$ & $467.988^{\cdots}$ & $399.195^{\text {w }}$ & $442.870^{\omega *}$ \\
\hline SIZE5 & 309.654 & 154.457 & 370.290 & $860.240^{* n}$ & $745.841^{\text {wat }}$ & $774.895^{* 2}$ \\
\hline SIZE6 & $1021.301^{\mathrm{wt}}$ & $863.578^{\cdots}$ & 977.228 w & $794.327^{\star \omega}$ & $676.958^{\cdots}$ & $704.071^{* \omega}$ \\
\hline SIZE7 & 669.095 & 618.543 & $736.412^{*}$ & $921.489^{\cdots}$ & $832.602^{\ldots}$ & $863.508^{* *}$ \\
\hline SIZE8 & $-1066.385^{n}$ & $-1161.020^{* 2}$ & $-1091.250^{\star *}$ & $-487.904^{*}$ & $-583.994^{*}$ & $-567.838^{*}$ \\
\hline SIZE9 & $2738.089^{w}$ & $2590.461^{\ldots}$ & $2972.039^{*}$ & $1913.182^{*}$ & $1788.967^{\cdots}$ & $2040.945^{*}$ \\
\hline SIZE10 & $1624.941^{\mathrm{m}}$ & $1512.554^{2 *}$ & $1552.862^{* \omega}$ & $1910.106^{*}$ & $1809.181^{\text {tw }}$ & $1787.432^{* *}$ \\
\hline FRA_HAIN & $\begin{array}{r}3.458 \\
(214.188)\end{array}$ & $\begin{array}{r}611.491^{*} \\
(323.609)\end{array}$ & $\begin{array}{l}521.786 \\
(324.051)\end{array}$ & $\begin{array}{r}-102.664 \\
(138.657)\end{array}$ & $\begin{array}{c}302.536 \\
(184.036)\end{array}$ & $\begin{array}{c}272.405 \\
(186.479)\end{array}$ \\
\hline FRA_GTSZ & $\begin{array}{l}910.196^{* *} \\
(298.127)\end{array}$ & $\begin{array}{c}460.261 \\
(347.600)\end{array}$ & $\begin{array}{l}730.989^{*} \\
(363.669)\end{array}$ & $\begin{array}{l}652.638^{*} \\
(167.483)\end{array}$ & $\begin{array}{l}404.881^{*} \\
(183.223)\end{array}$ & $\begin{array}{l}456.588^{*} \\
(195.464)\end{array}$ \\
\hline CHAIN"FRA_HAIN & & $\begin{array}{c}-1483.408^{* *} \\
(592.823)\end{array}$ & $\begin{array}{c}-1442.492^{*} \\
(591.609)\end{array}$ & & $\begin{array}{c}-1130.071^{\ldots 1} \\
(337.452)\end{array}$ & $\begin{array}{l}-1103.225^{\omega} \\
\quad(338.243)\end{array}$ \\
\hline SIZE4567FRA_GTSZ & & & $\begin{array}{c}-1538.910^{* *} \\
(645.091)\end{array}$ & & & $\begin{array}{l}-182.825 \\
(356.349)\end{array}$ \\
\hline SIZE890*FRA_GTSZ & & & $\begin{array}{c}-12853.040^{* 4} \\
(6315.867)\end{array}$ & & & $\begin{array}{c}-3336.420^{\circ} \\
(1667.659)\end{array}$ \\
\hline$n$ & 1407 & 1407 & 1407 & 3364 & 3364 & 3364 \\
\hline$R^{2}$ & 0.284 & 0.288 & 0.293 & 0.187 & 0.189 & 0.190 \\
\hline Adjusted $R^{2}$ & 0.200 & 0.171 & 0.176 & 0.179 & 0.181 & 0.182 \\
\hline$F$-statistic (prob.) & $2.42(0.000)$ & $2.45(0.000)^{2 *}$ & $2.49(0.000)^{k 2 .}$ & & & \\
\hline & 198 & 199 & 201 & 34 & 35 & 37 \\
\hline $\begin{array}{l}\text { Joint } F \text {-test of new } \\
\text { variables }\end{array}$ & & (1) vs (2) & (2) vs (3) & & (4) vs (5) & (5) vs (6) \\
\hline \multirow[t]{2}{*}{$F$-statistic (prob.) } & & $6.23(0.013)^{\mu *}$ & $4.68(0.009)^{\mathrm{wn}}$ & & $6.73(0.010)^{\omega *}$ & $5.17(.023)^{k}$ \\
\hline & \multicolumn{3}{|c|}{$\begin{array}{l}\text { Not shown: } 3 \text { quarterly and } 173 \\
\text { county dummies }\end{array}$} & \multicolumn{3}{|c|}{$\begin{array}{l}\text { Not shown: } 3 \text { quarterly and } 7 \\
\text { county dummies (statistical } \\
\text { software for unbalanced panel } \\
\text { GLS limits RHS variables to } \\
200 \text {, therefore only significant } 7 \\
\text { dummies of } 173 \text { possible } \\
\text { included) random effects are for } \\
\text { each of } 487 \text { zip codes }\end{array}$} \\
\hline
\end{tabular}

Standard errors in parentheses. 
While these two interaction effects are negative (-1538.91 and -12853.04 , respectively), the main effect of FRA_GTSZ is positive (730.99). Together these three coefficient estimates suggest that only small hotels gain from being in markets populated by larger hotels; medium and larger hotels are harmed when surrounded by larger hotels. What explains these negative coefficients? Again composition of customers provides a possible explanation. Customers might be different in their preferred size of hotel. A large hotel surrounded by more and more large hotels may find that the joint signaling is not enough to swing the customer composition sufficiently to offset the increased concentration of large hotels.

Given the negative effects that chains and large hotel experience, these negatives suggest that agglomeration is not only non-beneficial, but can in some situations be harmful for revenue performance. Likely most observations of such negative performance result when other hotels move into a location changing the market mix; existing incumbents may experience detrimental shifts in hotel composition.

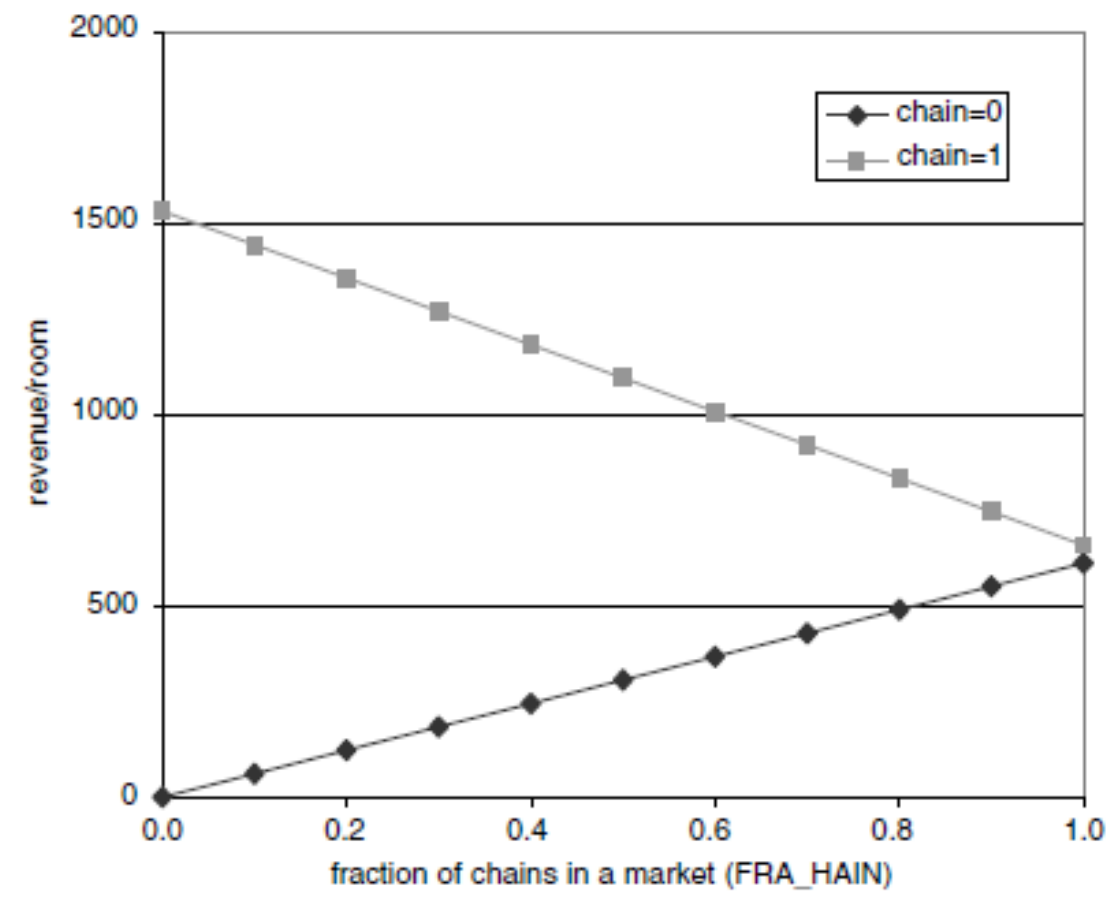

Figure 3. Chain affiliation agglomeration effect 


\section{CHECKS}

Before settling on these results, we try other specifications to examine the robustness of the above reported findings. First, since we address the potential lack of independence for multiple hotels operating in the same market by randomly selecting one hotel per zip code-quarter, we try several different random draws. The results from these other random draws are also qualitatively similar to those reported in sign and significance. This is unsurprising because our results are based upon variation obtained mainly from a cross market analysis. Our sample has many zip code markets (487 five digit zip code markets) and therefore our results are not inherently sensitive to which particular hotel is randomly drawn in each individual market.

As another check we use the entire sample (3364 observations) while including random-effects for the 487 zip codes. In this specification we also retain the equivalent of 2-way fixed-effects by including quarterly and county dummy variables. ${ }^{13}$ These results are shown in Table 4; columns 4, 5, and 6 . While some of the control variables attract different coefficient estimates, the results for the agglomeration measures and interaction terms are generally similar, though lower in magnitude to the corresponding ones in columns 1,2 , and $3 .{ }^{14}$

Another possibility that we investigate is excluding one-unit markets. Given the rural nature of Texas, numerous zip codes might have only one hotel. In such settings, the agglomeration measures clearly have less meaning. We investigate whether such observations substantially affect our results. We exclude all one-unit zip codes and repeat the analyses reported in Tables 3 and 4 . The number of observations with the random sampling drops from 1881 to 1028 indicating that single-unit zip codes are fairly common. With these fewer observations, we still support Hypothesis 1a that a hotel experiences better revenue performance when its rural market contains more hotels that are larger than itself, though only at $5 \%$ level versus $1 \%$. We also still find evidence contrary to Hypotheses $2 a$ and $2 b$ that independents and smaller hotels gain from chains and larger hotels, though the significance levels are again reduced.

Since our results are for rural markets, we investigate how robust our definition is of rural versus urban. We use PROC CLUSTER in SAS with density (population per square mile) as the clustering criteria. The clustering procedure maximizes between group variation while minimizing within group variation. While initially asking for three clusters that would correspond to rural, suburban, and urban; we find that a handful of super-urban markets (density of greater than 4,400 people per square mile) consumed the urban cluster. We iterated the number of clusters upwards from three, to four, to five, to six, to seven, to eight. Incrementing the number of clusters upwards refines the divisions between suburban, urban, and super-urban markets (more super-urban clusters are added), but does not influence the split between rural and suburban. Asking for four through seven clusters provides a split between rural and suburban markets at 975 people per square mile (with an average 113 people per square mile in

\footnotetext{
${ }^{13}$ While we included 173 dummy variables for all the Texas counties in our previously reported model specifications (OLS using one randomly chosen observation per zip code), with the move to a random effects model we were limited in the number of independent variables we could include. While originally using SAS, since SAS does not support unbalanced panel GLS models, we had to use LIMDEP, which has an upper limit of 200 right-hand-side variables. Therefore we are unable to include all our focal independent, control, and dummy variables. We made several runs using subsets of the 173 dummy variables to identify which are consistently significant in the presence of the focal independent and control variables. This yielded 7 significant county dummies which we include. Thus the models in columns 4, 5, and 6 have quarterly fixed-effects, county fixed-effects, and zip code random-effects.

${ }^{14}$ In comparing these results to those obtained in columns 1, 2, and 3 of Table 4; while the random-sampling-OLS sacrifices statistical power by using fewer observations, the ideal conditions that the error structure is i.i.d. are more likely maintained. When using the full sample, random-effects does not address a potential lack of independence - that unmeasured agglomeration effects can cause both positive and negative effects between units. The random-effect provides an identical offsets for all units within the same zip codes - either only positive or only negative. Between the two specifications, the trade off is lower statistical power and adherence to ideal conditions versus greater power but likely violation of ideal conditions.
} 
rural markets). Eight clusters provide a split at 430 people per square mile (44 people per square mile in rural markets). We then try our test specifications using this lower threshold split and find that results remain similar in sign, size, and significance.

\section{CONCLUSIONS}

While competition decreases rents, the presence of competitors may be beneficial. Agglomeration-firms locating near each other- can generate gains. Broadly, two types of agglomeration gains exist: production enhancements and heightened demand. With production enhancements, more firms can access leading techniques because their proximity aids flow of information between firms. With heightened demand, agglomeration helps consumers to first establish firms' existence and then to evaluate the options presented by these collacted firms, which increases visitation and subsequent purchases.

Focusing on a setting where heightened demand is likely from agglomeration, the lodging industry, we ask two questions. First, who contributes to heightened demand; how is it a function of the firms composing the market? Second, if heightened demand occurs, then who gains from it; how do a firm's traits increase or decrease the benefit from heightened demand? After controlling for numerous demand, supply, and establishment traits to eliminate obvious alternate explanations, we find evidence that agglomeration heightens demand, especially in rural markets where actions by firms to reduce consumers' search costs would be more effective. In rural markets, chain establishments and larger establishments create positive demand effects. Other factors held constant, a hotel in a market populated with a higher fraction of chain affiliated hotels and a higher fraction of larger hotels experiences higher revenues per room. Chain affiliation effectively signals unobservable quality, which likely draws more consumers. Larger establishments likely advertise more since they can spread this fixed cost across more units and this advertising also benefits other firms.

Further, firms benefit heterogeneously from these agglomeration effects. While expecting agglomeration gains to be localized - that firms similar to those creating the heightened demand would benefit the most, we find evidence of the opposite. While the presence of chains heightens demand, independent hotels do better in markets populated by more chain hotels. Also while larger firms heighten demand, small hotels' revenue performance increases when surrounded by larger hotels. Interestingly, medium and large hotels do worse when amidst larger hotels and chains do worse amidst chains.

While contrary to Hypotheses $2 \mathrm{a}$ and $2 \mathrm{~b}$, these findings are consistent with research in resource partitioning and examples provided by practitioners. ${ }^{15} \mathrm{~A}$ recent newspaper article reads:

Ramesh Patel bought The Tropics motel in Santa Rosa, CA, in 1977. For decades, the motel was an acrossthe-street neighbor to the queen of the Santa Rosa Avenue motels, the El Rancho Tropicana. Patel said his place benefited from proximity to the El Rancho, taking in people who were turned away when the larger resort illuminated the "No Vacancy" sign. Business dwindled after the closing of the El Rancho and Patel was

\footnotetext{
${ }^{15}$ With resource partitioning, Carroll (1985) suggests that generalists and specialists occupy different parts of a market niche and that as generalists increasingly dominate a market, specialists enjoy greater opportunities. Recent empirical examinations include Swaminathan (1995), Seidel (1997), and Mezias and Mezias (2000). We thank an anonymous reviewer for this interpretation.
} 


\section{forced to close the Tropics motel. ${ }^{16}$}

Further, our results complement Baum and Haveman (1997) who suggest firms choose locations to trade off competition losses versus potential agglomeration gains; consistent with their finding of Manhattan hotels dissimilar in size locating close together we find rural Texas hotels gain from heightened demand created by dissimilar hotels.

Our results suggest that firms should choose locations with care. Managers need to be aware that optimal location choice is not only a function of a location's traits, but also of the firm's own traits. Certain markets offer agglomeration gains, but not all firms can benefit from them. While a medium chain affiliated hotel would be wise to avoid a market with many large chains, a small independent would do well. That the small independent does well illustrates that some fears about category killers such as Walmart or Home Depot are misplaced. While all smaller establishments will not survive, our results suggest that some can thrive by enjoying heightened performance due to the presence of such large chains.

While showing benefits of agglomeration for small and independent hotels, caveats exist. First, we cannot observe differences in cost between small independents that do or do not agglomerate. Agglomerating independents may have to provide more services and higher quality for customers to switch from chain hotels. Second, given data limitations, we are unable to control for order-of-entry effects. For example, while a high revenue location may attract many chain hotel entries, an independent lucky enough to have been there in the first place will enjoy higher revenues than independents located in areas that chains have avoided. We leave an investigation of these phenomena for future work.

Further research might also focus on differences between agglomeration arising in rural versus urban markets. While seeing little evidence for agglomeration in urban Texas markets, urban markets are a more complex setting where firms from many different populations interact. These turbulent urban settings might be more interesting to managers than placid rural ones. Besides agglomeration creating heightened demand, similar investigation of when agglomeration enhances production, who contributes, and who gains is also needed. While future research is recommended, we believe that this paper is the first to empirically test how firm traits influence heightened demand arising from agglomeration and provides a starting point for further empirical exploration in more complex settings.

\section{ACKNOWLEDGEMENTS}

We acknowledge the helpful comments of Richard Arend, Nicholas Argyres, Avijit Ghosh, Andrew King, Julia Liebeskind, Steve Mezias, Tom Pugel, Bernard Yeung and two anonymous reviewers. Errors remain our own.

\section{REFERENCES}

Appleyard M. 1996. How does knowledge flow? Strategic Management Journal, Winter Special Issue 17: 137-154. Baum J, Haveman H. 1997. Love thy neighbor? Differentiation and agglomeration in the Manhattan Hotel industry,

\footnotetext{
${ }^{16}$ The Press Democrat Santa Rosa, CA, page B1, February 21, 1997.
} 
1898-1990. Administrative Science Quarterly 42(2): 304-339.

Baum J, Ingram P. 1998. Survival-enhanced learning in the Manhattan hotel industry, 1898-1990. Management Science 44(7): 996-1016.

Baum J, Mezias S. 1992. Localized competition and organizational failure in the Manhattan hotel industry, 18981990. Administrative Science Quarterly 37: 580-604.

Barnett W, Carroll G. 1987. Competition and mutualism among early telephone companies. Administrative Science Quarterly 32(3): 400-22.

Carroll GR. 1985. Concentration and specialization: dynamics of niche width in populations of organizations. American Journal of Sociology 90: 1262-1283.

Conlin M. 1999 An empirical analysis of the effect ofdivi- sionalization and franchising on competition. Working paper-Department of Economics, Cornell University.

Darr E, Argote L, Epple D. 1995. The acquisition, transfer and depreciation of knowledge in service organizations: productivity in franchises. Management Science 41: 1750-1762.

Dudey M. 1990. Competition by choice: the effect of consumer search on firm location decisions. American Economic Review 80: 1092-1104.

Eaton BC, Lipsey RG. 1982. An economic theory of central places. The Economic Journal 92: 56-72.

Fischer J, Harrington, Jr J. 1996. Product variety and firm agglomeration. RAND Journal of Economics 27(2): 281-309.

Ingram P. 1996. Organization form as a solution to the problem of credible commitment: the evolution of naming strategies among U.S. hotel chains. Strategic Management Journal, Summer Special Issue 17: 85-98.

Ingram P, Baum J. 1997. Chain affiliation and the failure of Manhattan hotels, 1898-1980. Administrative Science Quarterly 42: 68 -102.

Ingram P, Inman C. 1996. Institutions, intergroup competition, and the evolution of hotel populations around Niagara Falls. Administrative Science Quarterly 41: 629-658.

Jaffe A, Trajtenberg M, Henderson R. 1993. Geographic localization of knowledge spillovers as evidenced by patent citations. Quarterly Journal of Economics 108(3): 577.

Marshall A. 1920. Principles of Economics Macmillan: London.

Mezias JM, Mezias SJ. 2000. Resource partitioning, the founding of specialist firms, and innovation: the American feature film industry, 1912-1929. Organization Science 11(3): 306-322.

Milgrom P, Roberts J. 1986. Price and advertising signals of product quality. Journal of Political Economy 94(4): 796821.

Nelson P. 1970. Information and consumer behavior. Journal of Political Economy 78: 311-329.

Nichols M. 1998. Advertising and quality in the U.S. market for automobiles. Southern Journal of Economics 64(4): 922-939. 
Rao A, Qu L, Ruekert R. 1999. Signaling unobservable product quality through a brand ally. Journal of Marketing Research 36(2): 258-269.

Seidel M-D. 1997. Competitive realignment in the airline industry: a dynamic analysis ofgeneralist and specialist organizations under different network structures. Doctoral thesis, University of California-Berkeley.

Shaver JM. 1997. The effect of own-firm and other-firm experience on foreign direct investment survival in the United States, 1987-92. Strategic Management Journal 18(10): 811-824.

Shaver JM, Flyer F. 2000. Agglomeration economies, firm heterogeneity, and foreign direct investment in the United States. Strategic Management Journal 21(12): 1175-1193.

Stahl K. 1982. Differentiated products, consumer search, and locational oligopoly. Journal of Industrial Economics 31(1/2): 97-113.

Stigler GJ. 1961. The economics of information. Journal of Political Economy 69(3): 213-225.

Swaminathan A. 1995. The proliferation of specialist organizations in the American wine industry, 1941-1990. Administrative Science Quarterly 40(4): 653-681.

Thomas L, Shane S, Weigelt K. 1999. An empirical examination of advertising as a signal of product quality. Journal of Economic Behavior and Organization 37: 415-430.

Tirole J. 1988. The Theory of Industrial Organization. MIT Press: Cambridge, MA.

Wernerfelt B. 1988. Umbrella branding as a signal of new product quality: an example of signaling by posting a bond. RAND Journal of Economics 19(3): 458-466.

West DS. 1992. An empirical analysis of retail chains and shopping center similarity. Journal of Industrial Economics 40(2): 201-221 